DOI:10.30842/ielcp230690152246

M. N. Kazanskaya

\title{
WHAT WAS THE NAME OF MIMNERMUS' FATHER?
}

Имя отца Мимнерма сохранилось в биографической справке $C y \partial ы$

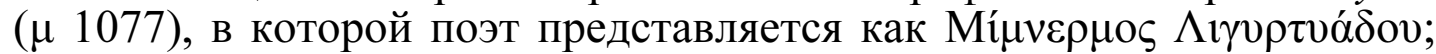
ни один другой источник имени отца поэта не сохраняет. Несмотря на то, что a priori серьезных причин подвергать это имя сомнению нет, его сложно сочетать с солоновским обращением к Мимнерму

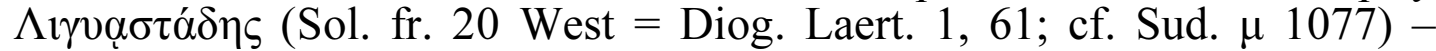
обращение, которое очевидно представляет комплимент Мимнерму, но, как кажется, обыгрывает имя не самого поэта, а его отца. В статье разбираются сильные и слабые стороны существующих подходов к

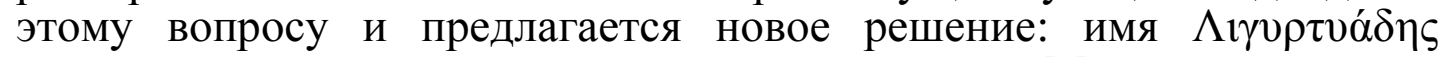
следует интерпретировать не как имя отца Мимнерма, а как

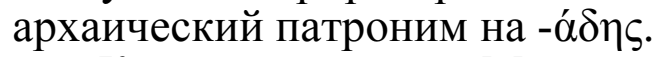

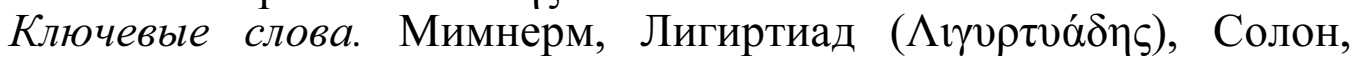
патроним, Суда, Диоген Лаэрций, античная филология, ономастика Малой Азии.

The only source to preserve the name of Mimnermus' father is the Suda lexicon which mentions it, together with the information on the elegist's birthplace, date and poems, in a short biographical entry ${ }^{1}$ :

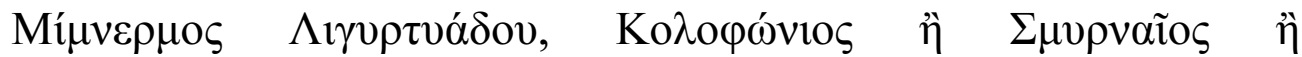

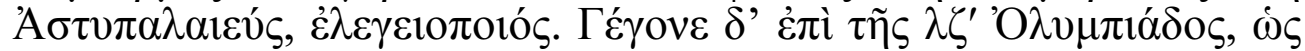

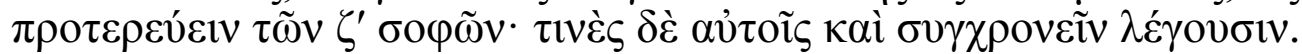

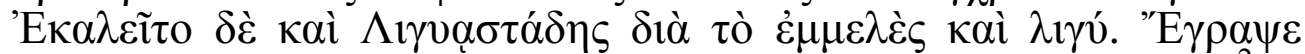

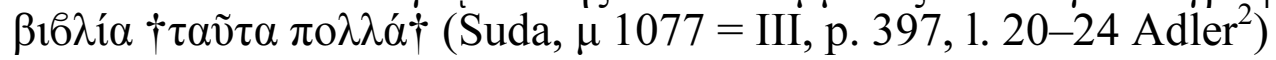

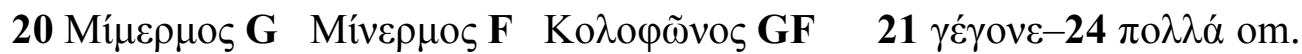

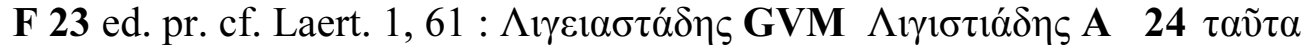

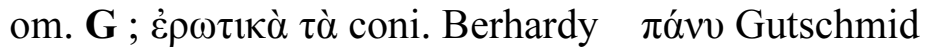

"Mimnermus, son of Ligyrtyades, from Colophon, or Smyrna, or Astypalaea, an elegiac poet. He lived ${ }^{3}$ in the $37^{\text {th }}$ Olympiad (i.e.

\footnotetext{
${ }^{1}$ Suda's entry on Mimnermus is usually placed at the head of the testimonia in editions of Mimnermus, so that this text is also cited as Test. 1 Gentili-Prato, Test. 1 Allen, Test. 1 Gerber, but Test. 77 SzádeczkyKardoss.

${ }^{2}$ References to manuscripts of Suda follow those used by Ada Adler in her edition: G - codex Parisinus 2622, V - codex Vossianus Fol. 2, M - codex Marcianus 448, F - codex Laurentianus 55, 1.

${ }^{3}$ The verb $\gamma \varepsilon$ ' person lived, and as such is close to, but less pointed than $\ddot{\eta} \kappa \mu \alpha \sigma \varepsilon v$ (floruit). On the ancient estimates of Mimnermus' date, see below.
} 
632-629 BCE), so that he precedes the Seven Sages; however, some say he was their contemporary. He was also called $\Lambda \imath v \alpha \alpha \sigma \tau \alpha \dot{\delta} \eta \zeta$, because of his melodiousness and clearness (of voice). He wrote books..."

The end of this passage is damaged beyond correction ${ }^{4}$, and there are variant readings for Mimnermus' alternative name

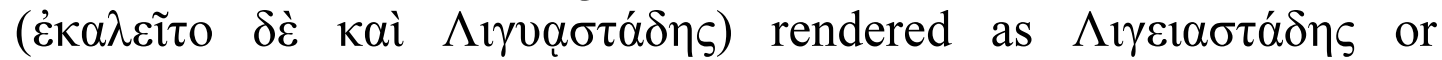
$\Lambda \imath \gamma \imath \sigma \tau \mid \alpha ́ \delta \eta \varsigma$ in the manuscripts (these variants will be discussed below). The beginning of the entry, on the other hand, is well preserved with only minor divergences in the manuscripts. Thus,

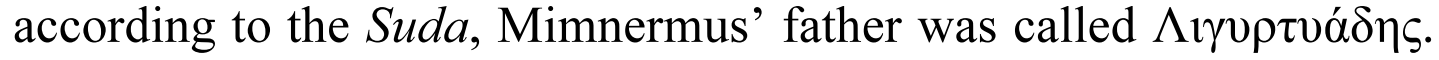
The manuscripts are in perfect accord as to the name, giving no variant readings, and a priori there would be little reason to doubt this information: no other source survives to contradict the Suda, and the obscurity of the name (as to the inner form) can be used in itself as an argument in favor of the compiler's accuracy ${ }^{5}$. This being said, modern scholars for the most part do not seem to be at ease with the name Ligyrtyades: it is never mentioned without a pointed reference to Suda and as often as not omitted altogether ${ }^{6}$. Neither is this uneasiness dispelled, when Ligyrtyades is compared with the poetic pseudo-patronym by which Solon addresses Mimnermus, urging him to modify the verse where he expressed his wish to die at sixty (Sol. fr. 20 West $=$ fr. 26 Gentili-Prato):

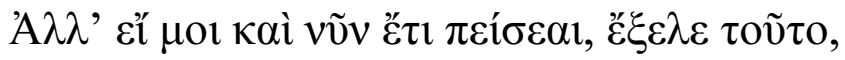

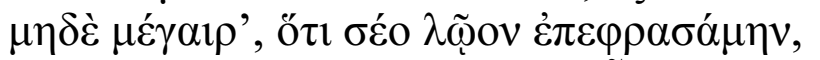

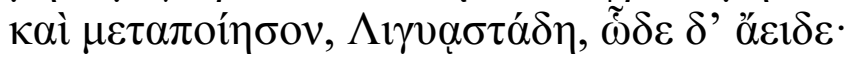

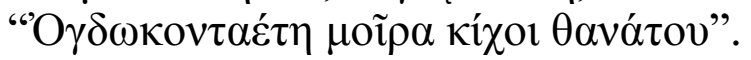

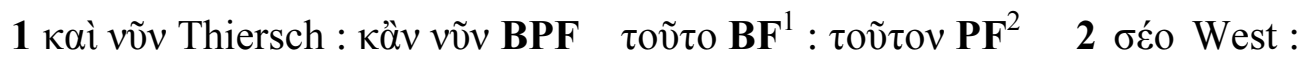

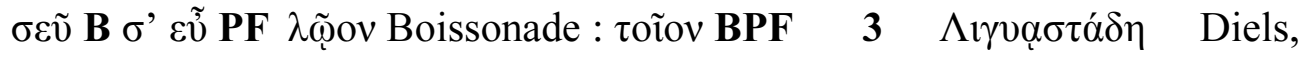

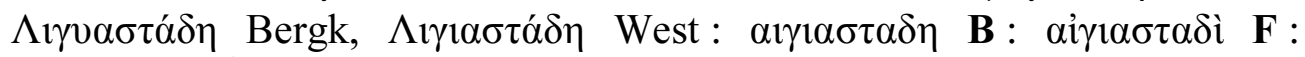

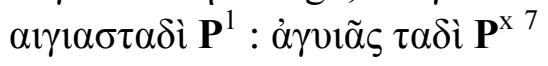

${ }^{4}$ For a list of corrections proposed for $\beta 16 \lambda i \alpha$ † $\tau \alpha \tilde{v} \tau \alpha \pi \mathrm{o} \lambda \lambda \dot{\alpha} \dagger$ †, see Allen (1993: 23); for the full discussion of the number of books in the Alexandrian edition of Mimnermus, see Müller (1988).

${ }^{5} \mathrm{Cf}$. Allen (1993: 16): "it is more likely that the mock patronymic plays on

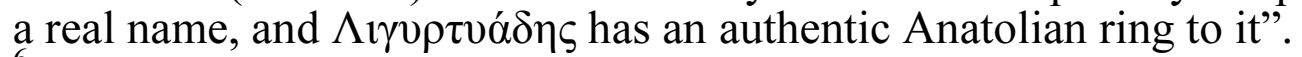

${ }^{6}$ Thus, the name Ligyrtyades is mentioned by Szádeczky-Kardoss (1968: 940), Schmid, Stählin (1929: 361 n. 6), Bagordo (2011: 165), but omitted by Barron, Easterling (1984: 133-134), Gerber (1997: 108-109).

${ }^{7}$ References to manuscripts follow those used by Tiziano Dorandi in his edition: B - codex Neapolitanus III B 29; P - codex Parisinus gr. 1759; F codex Laurentianus 69.13. 
"But should you believe me now as well, remove it, and begrudge me not that I surpassed you by my inventiveness, and change it,

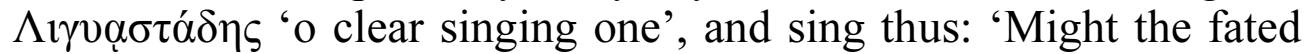
death overtake me at the age of eighty"'.

This fragment (together with Mimnermus' distich that prompted Solon's response) is preserved by Diogenes Laertius and is one of the best-known poetic dialogues in ancient literature. As may be seen from the apparatus criticus, the transmitted text has prompted a number of emendations ${ }^{8}$ : as there are numerous discussions of the text, we will only examine the reconstruction of the apostrophe, as relevant for the needs of this article. The scribes seem to have been confused as to its form, so that the manuscripts read with minor variations АІГІА $\mathrm{TA} \Delta \mathrm{H}(-\mathrm{I})^{9}$, with one attempt at correcting the unintelligible combination of letters into words (âyviãs $\tau \alpha \delta i$ ). However, early on Suda's information that Mimnermus was also called $\Lambda \imath \gamma \varepsilon \imath \alpha \sigma \tau \alpha ́ \delta \eta \varsigma$ or $\Lambda \imath \gamma \imath \sigma \tau \imath \alpha ́ \delta \eta \varsigma$ (ms. reading), was connected with the Solonian fragment and used to reconstruct Solon's apostrophe to Mimnermus. Thus, Bergk accepted the correction

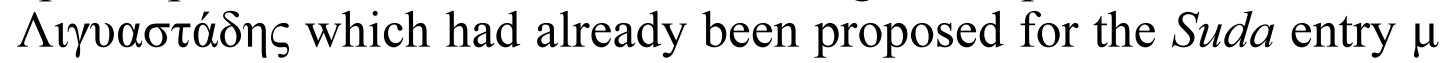
1077 by the lexicon's first editor, Demetrios Chancondylas, as a

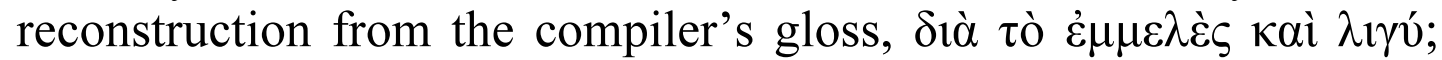
Bergk accordingly incorporated the emended form into his edition of the Solonian fragment in the vocative, $\Lambda \jmath \gamma v \alpha \sigma \tau \alpha \dot{\delta} \delta \eta^{10}$. Later Diels

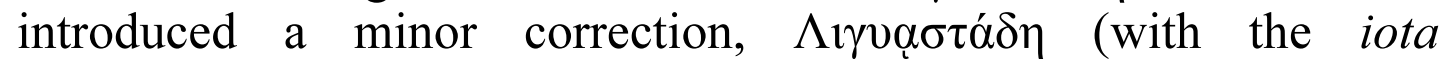
subscriptum), thereby connecting Solon's coinage with $\lambda$ irv̀ ố $\delta \varepsilon v$ and establishing a pun between the apostrophe and following

${ }^{8}$ For the discussion of the textual variants and proposed corrections, see Tuomi (1986: passim), Noussia-Fantuzzi (2010: 402-404). More particularly on the much debated question of whether kòv võv should be

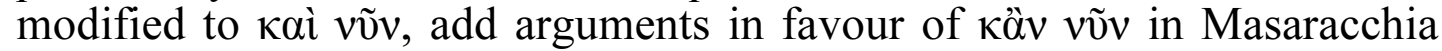
(1958: 335) and Perrotta, Gentili (1965: 27), as well as West's defence of Kaì võv (1974: 182). The correction Kaì võv is also endorsed by Dovatour (1982), and even becomes an important point in his argument, but the preference is left unexplained.

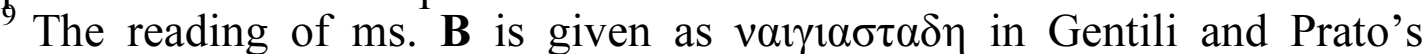
edition (1979: 118); however, it is clearly a dittograph of the ending the previous word, $\mu \varepsilon \tau \alpha \pi \circ$ ínбov, and Dorandi (2013: 102) simplifies it to $\alpha i \gamma 1 \alpha \sigma \tau \alpha \delta \eta$ in his apparatus criticus.

${ }^{10}$ See Bergk (1843: 331) who is followed by Hudson-Williams (1926: 67)

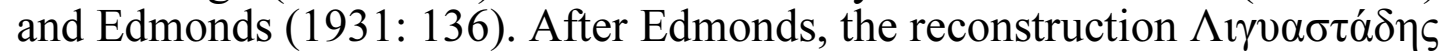
has been largely neglected for some decades but was recently defended by

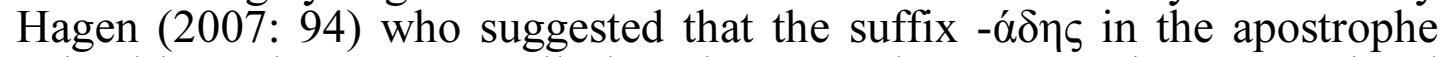
coined by Solon may actually be reinterpreted as a second root associated

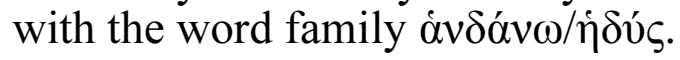


imperative, $\tilde{\omega} \delta \varepsilon \delta$ ' $\alpha \varepsilon 1 \delta \varepsilon$ : this reconstruction is widely accepted and has become the predominant reading in editions of elegiac poets ${ }^{11}$. However, there are obvious risks in relying on a corrected text in order to emend manuscript readings of another text, and M. L. West, in order to escape the trap of a circular argument, reconstructed for Solon's address to Mimnermus (fr. 20, 3 W.) the form $\Lambda \imath \gamma 1 \alpha \sigma \tau \alpha \delta \delta \eta$ solely on the basis of paleographical data ${ }^{12}$. West is followed by Marcovich (1999: 41), but most editors only mention the proposed variant in their apparatus. The implications of West's approach will be discussed below; let us just note, for the moment, that in this case, prudence is counterintuitive, as it neglects Suda's gloss $\delta i \alpha ̀$ tò $\dot{\varepsilon} \mu \mu \varepsilon \lambda \hat{\varepsilon} \varsigma \kappa \alpha \grave{~} \lambda \iota \gamma v$ and eliminates any idea of wordplay in Solon's apostrophe.

Thus, of the three proposed corrections for Solon's address to

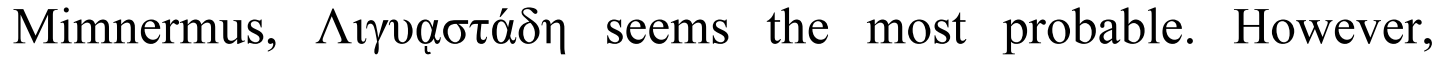
whichever one chooses to retain, one detail remains unchanged: Solon's address to Mimnermus, leaving aside its probable poeto-

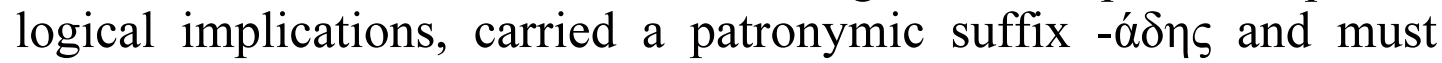
have played on the poet's real patronym. But a form of this kind is hard to reconcile with Suda's report that Mimnermus' father was

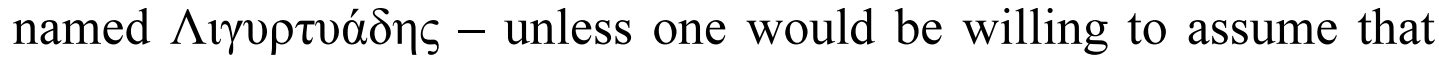

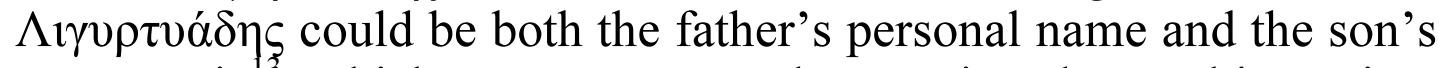
patronymic $^{3}$, which runs counter to the practice observed in ancient

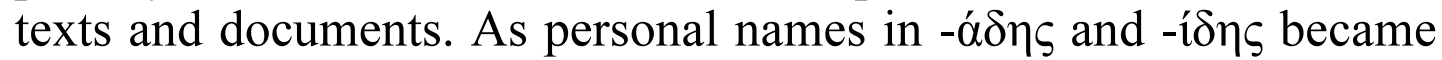
more frequent in Greece, the language took steps to prevent confusion with former adjectival patronyms with the same suffix. Thus, in most dialects, when a father bears a name of this type, the

${ }^{11}$ For the first suggestion, see Diels (1902: 482); the correction was accepted by Diehl (1954: 40), Masaracchia (1958: 335), Gentili and Perrotta (1965: 27), Campbell (1967: 36), Gentili and Prato (1979: 118), Gerber (1995: 140), Noussia-Fantuzzi (2010: 110; cf. 403-404 with argumentation). Sometimes the apostrophe is printed as a common word, not a name - $\lambda ı \gamma v \alpha \sigma \tau \alpha ́ \delta \eta$ (cf. Gentili, Perrotta 1965: 27; Diehl 1954: 40).

${ }^{12}$ The form appeared in the first 1972 edition of Iambi et elegi Graeci, and was retained by West in his second, reworked edition (West 1992: 152), as well as in his Delectus ex iambis et elegis Graecis (West 1980: 172). West explained his editorial decision in the following way: "I have given the patronymic in the form presupposed by the tradition (D.L. + Suda). Obviously $\Lambda \mathrm{v} v$ - is the slightest of changes; but I do not regard the rest of the name as clear. I would be disturbed to meet such a form as ớ $\sigma \tau$ tn in early poetry. $\lambda i^{\prime} \gamma^{\prime}$ i $\alpha \sigma \tau i$ is no more plausible as analysis" (West 1974: 182). ${ }^{13}$ A strand of ancient exegetical tradition which could be used to

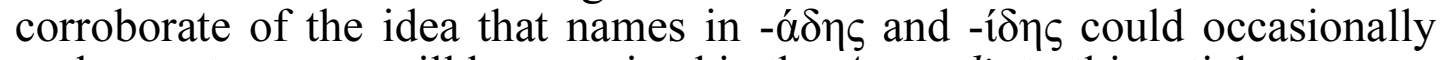
replace patronyms, will be examined in the Appendix to this article. 
son's parentage can only be expressed by a genitive: e.g. $\Delta \varepsilon \imath v o ́ \sigma \tau \rho \alpha-$

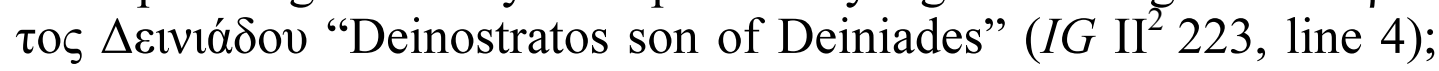

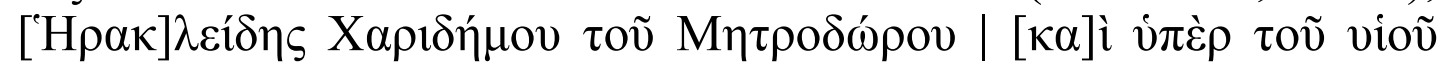

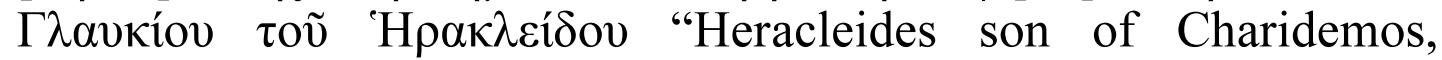
grandson of Metrodoros [contributed], as well as on behalf of his son, Glaucios son of Heracleides" (CIG $3141=$ ISmyrn. 688, lines 10-11). The Thessalian dialect, on the other hand, which used adjectival patronymics, took care to distinguish these forms by a

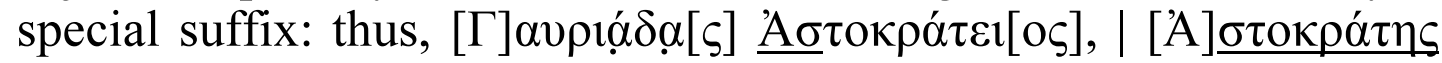

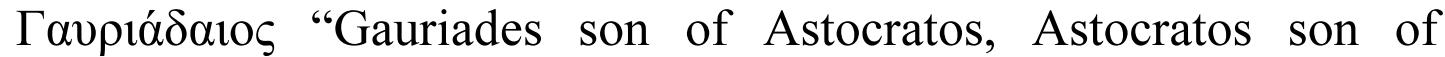

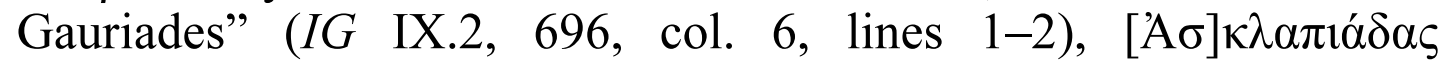

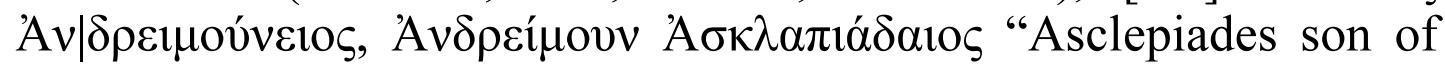
Adreimon, Andreimon son of Asclepiades" (IG IX.2, 517, lines 63$64)$; in both cases where the names recur in every second generation.

Although this discrepancy in the sources is rarely emphasized by scholars, attempts have been made to explain it away. The most popular solution, proposed already by Diels, postulates that by

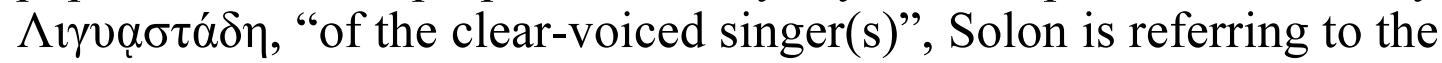
fact that Mimnermus belonged to a poetic group or a professional

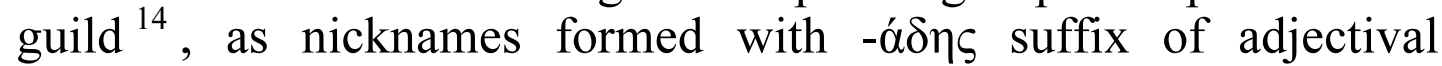
patronyms are frequent in poetry. Thus, Diels and Noussia-Fantuzzi found resemblance with Aeschylus' apostrophe to Dionysus in the

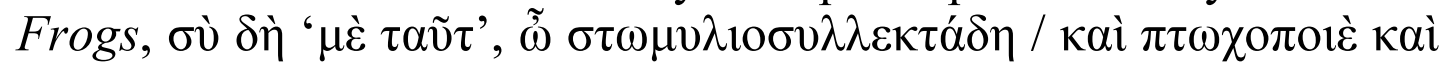

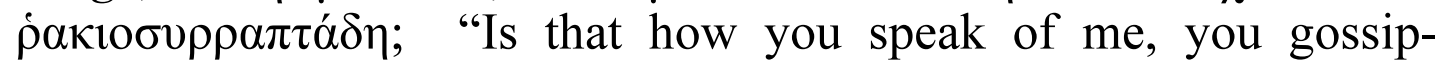
gleaner, you creator of misers, you rag-stitcher?" (Aristoph. Ran. $841-842)^{15}$; given the mocking tone of the passage, this might not be the ideal parallel for Solon's compliment. Perotta and Gentili (1965: 28), on the other hand, cite a parallel from a fragment of Sophocles' Inachus that may seem closer from the point of view of tonality to the affection (albeit tinged with gentle irony) of Solon's apostrophe:

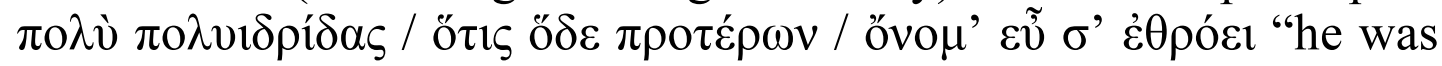
of very very astute stock, whoever it was among our forefathers who

\footnotetext{
${ }^{14}$ Diels (1902: 482): "Das patronymische Suffix, das an $\lambda$ ivvớ $\sigma \tau \eta \varsigma$ antritt, soll die Zugehörigkeit zur Zunft der , hellen Sänger ' bezeichnen”.

${ }^{15}$ See Diels (1902: 482), Noussia-Fantuzzi (2010: 402-404). However, when one compares Dover's note on the formation, the stylistic connotations do not seem to match well. Dover (1993: 297-298, on v. 841)

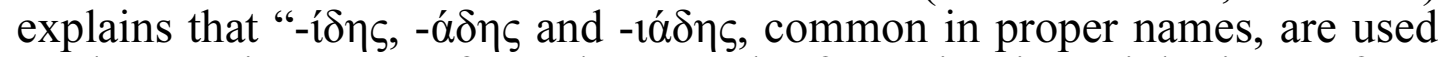
to characterize types of people [...] The formation is an inheritance from early iambic poetry $[\ldots]$, and appears in satyr drama”.
} 
rightly spoke of your name..."16. Finally, Gerber and Allen interpreted the compound as referring to Mimnermus' actual descent from a family of singers ${ }^{17}$. It should be noted, however, that the

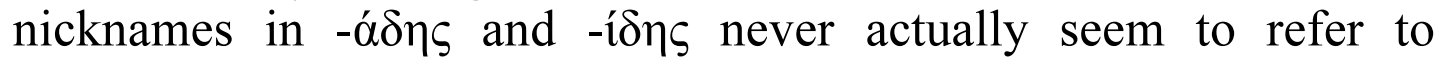
parentage, but rather to the idea that the person is a worthy representative of his class, group, or profession ${ }^{18}$. Thus, while the parallels explain the dynamics of Solon's wordplay, the reasons why he chose to make the name of Mimnermus' father rather than the poet's own name or patronymic the focus of his pun remain unclear. Indeed, Meyer when commenting on Solon's coinage, does not even mention its resemblance to the name Ligyrtyades transmitted by the Suda.

With a twist on the previous explanation, M. Noussia-Fantuzzi

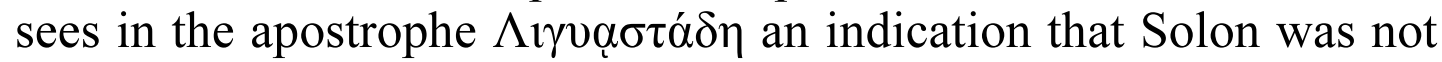
actually addressing Mimnermus but replying, in the context of a poetic play at a banquet, to a fellow symposiast who had just quoted Mimnermus' verse, and that his word-play was meant to acknowledge Mimnermus' authorship of the verse, while the apostrophe could be applied to any reciter ${ }^{19}$. While this approach tries to escape the question of whether an actual poetic dialogue could be possible between the two poets (the problem will be discussed below), it also dissociates the apostrophe $\Lambda$ $\gamma v \alpha \sigma \tau \alpha \dot{\delta} \delta \eta$ from Mimnermus; but even so, the resemblance of the apostrophe to the name of Mimnermus' father, and not to the poet's patronymic remains unexplained.

${ }^{16}$ P. Tebt. 692, lines 16-18: for the text, see Carden (1974: 73), who also

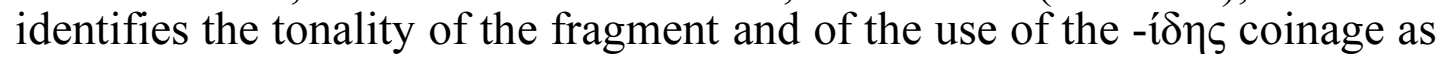
"jocular" (cf. Carden 1974: 82). As regards the Solonian fragment, the tone

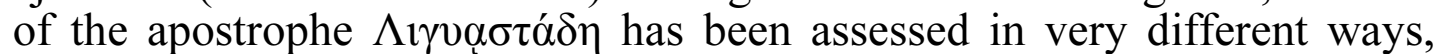
ranging from "mocking" (thus, Tuomi 1986: 10-14) to "full of reverence" (thus, Steffen 1955: 44).

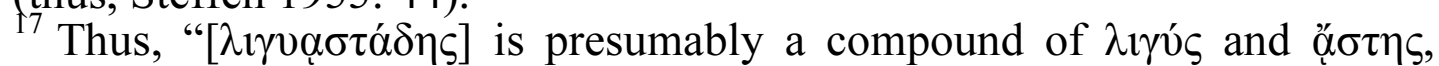
hence literally "son of a clear singer" " (Gerber 1970: 138); cf. "[Solon] addresses Mimnermus, not as the son of a particular father, but as a poet who belongs to a family of clear-voiced singers" (Allen 1993: 15-16).

${ }^{18}$ As Meyer (1923: 116) explains the basic semantic nuance proper to this type of word formations, "die Endung $-1 \delta \eta \varsigma(-\alpha \delta \eta \varsigma)$ gibt dem Kompositum den Wert von etwas Dauerndem weil ,erheblich von Geschlecht zu Geschlecht Weitergegebenem“; d.h. etwas von Hause aus Angeborenem".

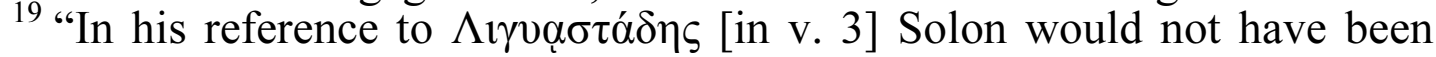
addressing the real Mimnermus by name (indeed what Solon utters is not Mimnermus' name), but rather he would have been signaling - outside of the fiction - that he was going to introduce a quotation from 'Mimnermus'” (Noussia-Fantuzzi 2010: 400-401). 
A more radical solution for the problem that the unexpected resemblance of the poetic pseudo-patronym and the name of Mimnermus' father poses is to postulate a corruption in the form

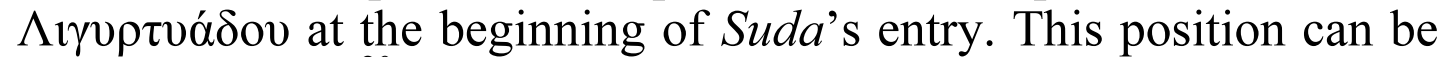
stated explicitly ${ }^{20}$, but more often than not it is implied, as, for example, or when Dihle says, without elaborating, that the apostrophe was based on "a patronym" disadvantage, as it gives a simpler, more transparent form preference over a more complex one; moreover, it implies that the name of Mimnermus' father could have been known to the compiler of the Suda entry solely from Solon's fragment, which, in our view, should not be taken for granted.

Finally, it has been suggested that the apostrophe in Solon fr. 20, 3 might be Mimnermus' actual patronym. Thus, when West reconstructs $\Lambda \imath \gamma \imath \alpha \sigma \tau \alpha \dot{\delta} \eta$, his editorial choice testifies above all to his doubts as concerns the text transmitted by manuscripts of Suda and Diogenes Laertius; however, since he makes no mention whatsoever

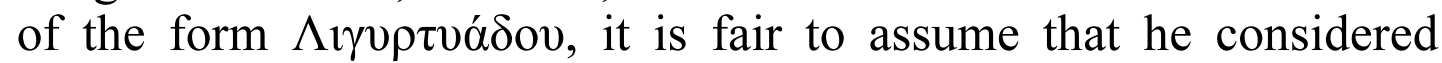
$\Lambda \imath \gamma \alpha \sigma \tau \alpha \dot{\delta} \eta$ as the closest we can get to recovering Mimnermus' patronymic. Hudson-Williams was more explicit: he suggested that

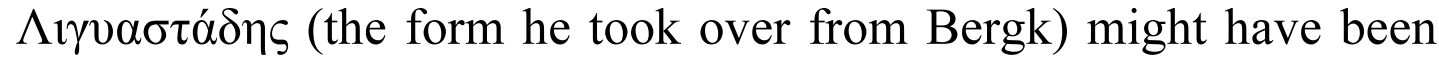
Mimnermus' real patronymic, which allowed him to surmise that Mimnermus' father was called Ligyastes ${ }^{22}$. In spite of all their differences, these attempts have two major drawbacks: (a) they are based on the assumption that there is no wordplay in Solon's fr. 20, 3 , which runs counter to the spirit of the Solonian fragment; and (b)

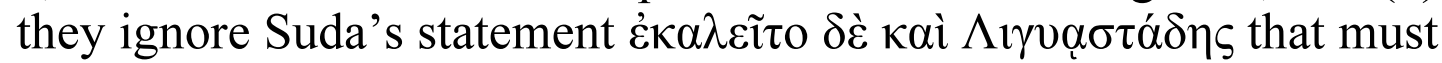

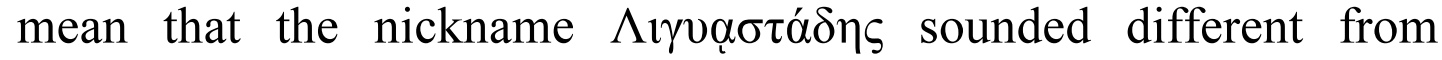
Mimnermus' name and patronymic - unless, of course, one is

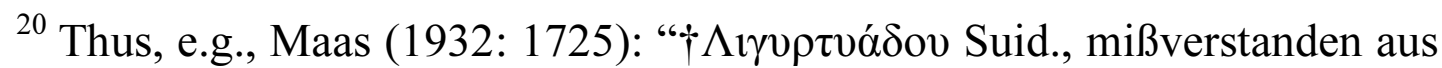
Solon frg. 2 D.". However, scholars stop short of proposing a correction for

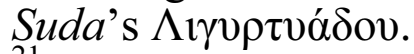

${ }^{21}$ Cf. Dihle (1962: 265 n. 1): "die einem Patronymikon nachgebildete und an seine Stelle stehende, vielleicht ironisch-scherzhafte Anrede $\lambda ı v 0 \alpha \sigma \tau \alpha ́ \delta \eta$ s, die Solon (fr. 22) gebildet hat".

${ }^{22}$ Hudson-Williams (1926: 127): "the poet may really have been the son of Ligyastas". The idea is mentioned critically by Noussia-Fantuzzi (2010: 404), but ignored by most other scholars. Edmonds (1931: 137) seems to have been the only scholar to have shared Hudson-William's approach, as

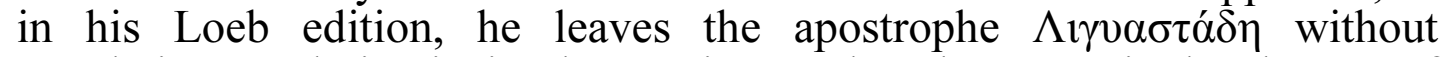
translation, rendering it simply as 'Ligyastades'; however, in the absence of a note, this is only a guess. 


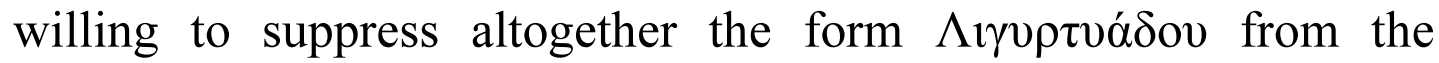
beginning of the Suda entry on Mimnermus.

Neither of these approaches recommends itself: one proposes a largely unwarranted modification to Suda's entry, and the other fails

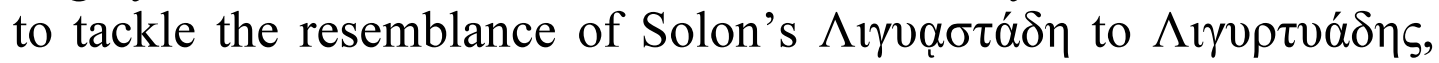
the name of Mimnermus' father as transmitted by the tradition. We are thus left with the question with which Szádecky-Kardoss ended his brief summary of the problem: "Wie und warum hätte man die

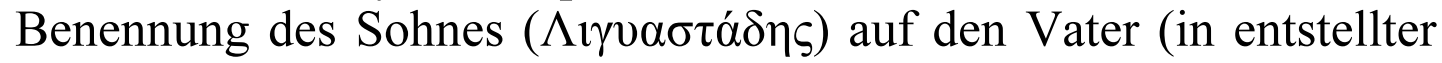
Form) übertragen?" (Szádecky-Kardoss 1968: 940).

There is one solution that has not been hitherto proposed and which would eschew the disadvantages of the approaches outlined above. However, before presenting it, a few words must be said about Mimnermus' biography in the Suda ( $\mu$ 1077) and on the sources used by its compiler. Its contents and structure of this entry are simple and straightforward, incorporating essential data on Mimnermus (father's name, place of birth, date, writings). However, the introduction of an alternative date, and especially the wording,

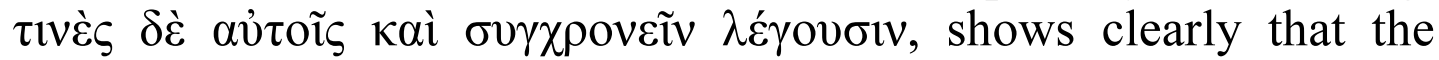
compiler relied on two distinct biographical sources on Mimnermus' life. One of these (preferred by the compiler) dated Mimnermus around 40 years (i.e. ten Olympiads) before the Seven Sages ${ }^{23}$, whereas the second made Mimnermus their contemporary: there can be little doubt that the later date stems from Solon's biographical tradition and was invented to account for the impression of a direct dialogue between the two poets that Solons' fr. $20 \mathrm{~W}$. leaves. The same biographical source would have provided the information that Mimnermus was also called $\Lambda \jmath \gamma v \alpha \sigma \tau \alpha \dot{\delta} \eta\rceil \varsigma$ (obviously taken directly from Sol. fr. $20 \mathrm{West}^{24}$ ). However, other data manifestly come from an independent biographical tradition: thus, the compiler is unsure about Mimnermus' place of birth, giving three possibilities,

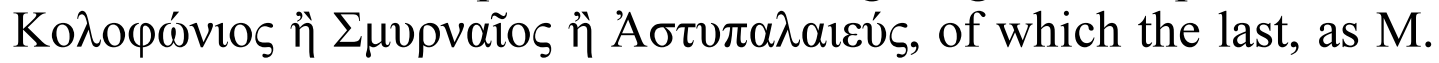
L. West has shown, must be a misunderstood periphrastic reference to Smyrna as the old $\mathrm{city}^{25}$, and the remaining alternatives probably

${ }^{23}$ On this calculation, see Sanz-Morales (2011: 34-35), who builds on an old idea briefly mentioned by Diels (1902: 482-483).

${ }^{24}$ For the idea that the Suda entry on Mimnermus relies on a combination of two traditions, see V. de Marco in della Corte et al. (1971: 23); cf. Wilamowitz (1913: 280, n. 1). Unfortunately, I was not able to consult de Marco (1939/40).

${ }^{25}$ See West (1974: 72), who is followed by Allen (1993: 13 n. 17), Gerber (1997: 109), Bagordo (2011: 165). 
reflect Mimnermus' elusive self-identification (as exemplified by Mimn. fr. 9 W. $)^{26}$; the information on the elegist's \&uvre, despite the corrupt state of the text in this passage, no doubt goes back to the organization of Mimnermus' Alexandrian edition ${ }^{27}$.

Returning to the question of the name of Mimnermus' father, it

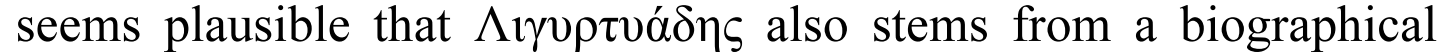
tradition on Mimnermus which could have learnt it either from an independent source or directly from the poet's writings. A look at the testimonia in modern editions of Mimnermus shows that hardly any of the meager details on the poet's life can be shown to have been preserved independently of Mimnermus' verses; this, as well as the fact that Solon had to know the name in order to create the

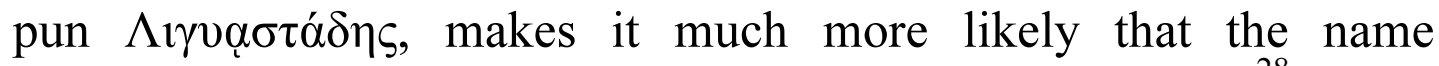
$\Lambda$

There is, in fact, one type of context where Mimnermus could have mentioned the name of his father - in a poetic sphragis to a large poem (such as the Smyrneis) or a book of poetry ${ }^{29}$. That Mimnermus might have "signed" his work is actually very probable. Pausanias tells us that the elegy on the Smyrneans' battle with the army of Gyges opened with a proem which spoke of two generations of Muses (Paus. 9, 29, $4=$ Mimn. fr. 14 Allen = fr. 13 West), a precious testimony which shows that Mimnermus payed attention to the formal framing of his work. A formalized proem of this kind (or, perhaps, an equally formalized closure of the book of poetry or a large poem) would be a perfect opportunity for inserting a sphragis. ${ }^{30}$ Now, in a context of this kind the name of the father would most certainly have appeared in the genitive form - in other

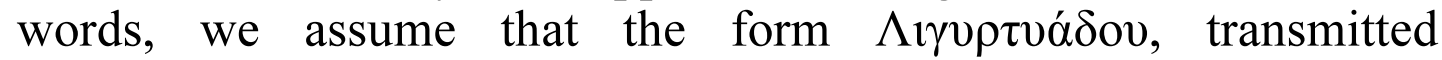
unanimously by the Suda manuscripts, was taken directly from Mimnermus' verses. If we further assume that Mimnermus' own

${ }^{26}$ See West (1974: 72), Allen (1993: 13-14), Gerber (1997: 109).

${ }^{27}$ On the reconstructions of Mimnermus' Alexandrian edition, see Müller (1988: esp. 206-208); Allen (1993: 19-23).

${ }^{28}$ The idea that the name Ligyrtyades could not have been mentioned by Mimnermus himself is sometimes presented as a self-evident premise (thus, Maas 1932: 1725), but, in our view, would need to be argued.

${ }^{29}$ On the sphragides in Greek poetry, see the seminal article by Kranz (1961), as well as discussions of seals of particular authors, such as Woodbury (1952), Hubbard (2007), Nisbet, Hubbard (1978: 335) and others.

${ }^{30}$ As Walter Kranz has shown, the form of invocation to the Muses (the $\kappa \lambda \eta \tau \imath \kappa o ̀ \varsigma ~ v ̋ \mu \nu \rho)$ in particular is associated with the poet's introduction of himself (Kranz 1961: 4-5). 
name was in the genitive, as is often the case in seals ${ }^{31}$, the combination of name and patronymic might have sounded as

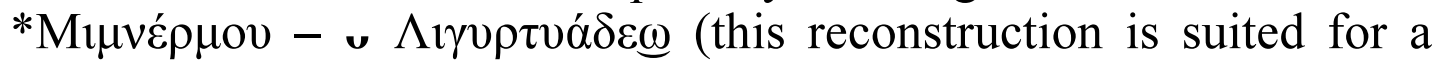

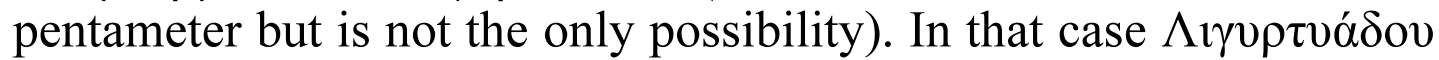

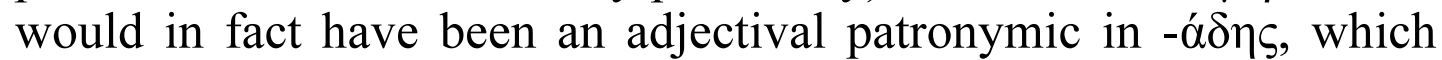
the compiler of the Suda or his source had interpreted as the father's name (on the reasons why such an interpretation seemed possible, see the Appendix to this article). In that case, Mimnermus' father would have actually been called $\Lambda$ i $v \rho \tau v \dot{\eta} \varsigma^{32}$.

Now, $\Lambda$ ivoptóns is not transparent as to its inner form, and its ending in -v́n $\varsigma$ is not typical for Greek names. However, names in -vๆ / -vas are fairly well attested in Greek inscriptions of Asia Minor $^{33}$, e. g., Touns (in Cilician and Pamphylian context) ${ }^{34}$, Пак-

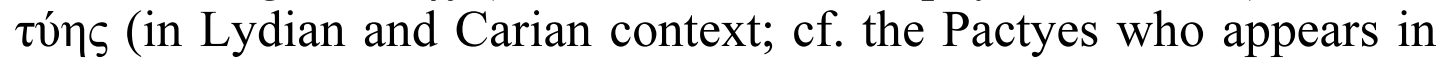

${ }^{31}$ The most famous sphragis of this kind is, of course, Theognis' seal: $\tilde{\omega} \delta \varepsilon$

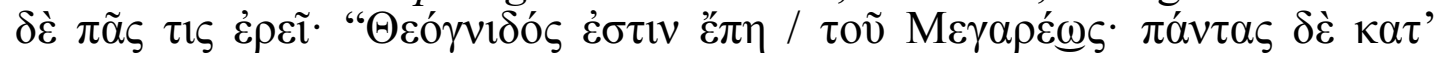

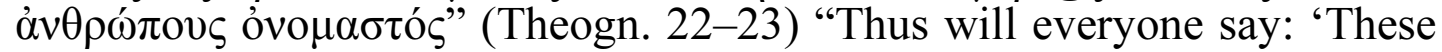
are the verses of Theognis, the poet from Megara, and his name is known

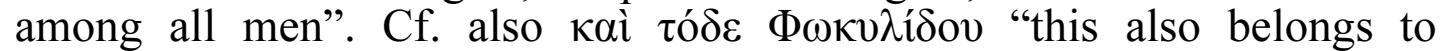

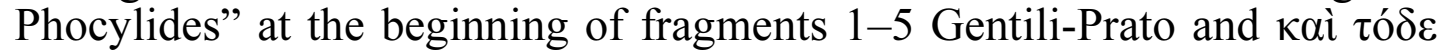
$\Delta \eta \mu о \delta$ кол "this too belongs to Demodocus" (Demodoc. fr. 2 W.; cf.

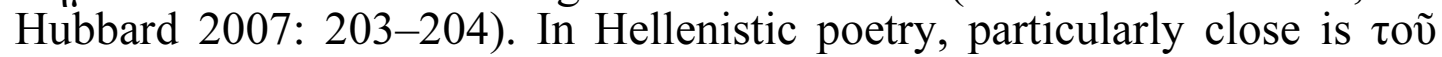

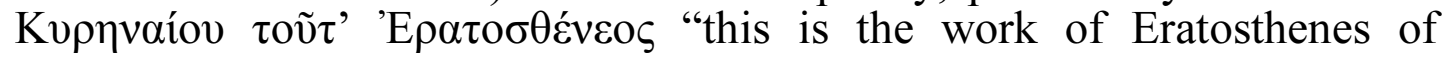
Cyrene" (Eratosthen. fr. 18, 35; cf. Nic. Ther. 957-958; cf. Alex. 629-630).

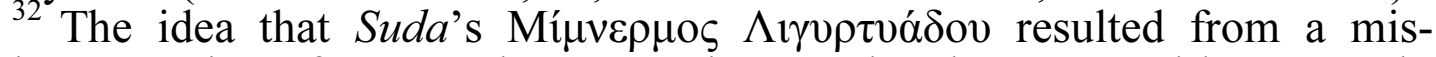
interpretation of an actual patronymic was already suggested by N. Bach; he used it, however, to argue that $\Lambda$ vop signaled Mimnermus' belonging to a group of singers: "Mimnermus non

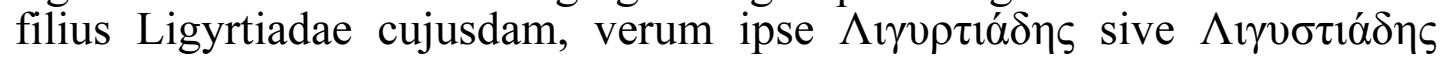
appelletur, forma quidem patronymica, illa tamen ad artem referenda, eadem prorsus ratione, qua Homeridae, Daedalidae aliique dicuntur" (Bach 1826: 8). The same idea also prompted Hudson-Williams' suggestion that

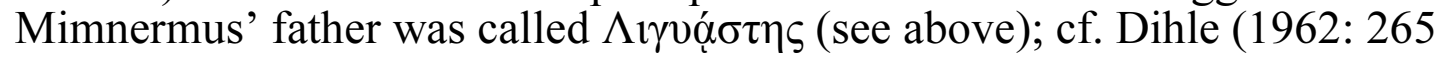
n. 1).

${ }^{33}$ The names in -vn 5 were gathered from the reverse index in the Lexicon of Greek Personal Names, vol. V.B (Frazer, Matthews 2013), but the list

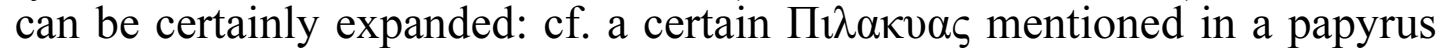
from Cairo and identified as a Pisidian by Louis Robert (1963: 428). We follow the editors of the Lexicon in leaving most of the names unaccented;

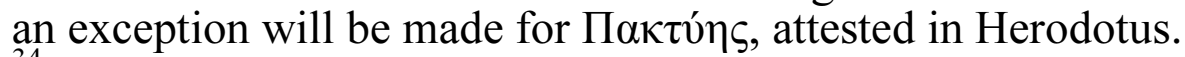

${ }^{34}$ Fraser, Matthews (2013: 412, s.v. Touns), Zgusta (1964: 520, 1585-4). The name can be identified with the Hittite name Duwa attested in several inscriptions (Laroche 1966: 193, no. 1398; the Hittite does not distinguish between /d/ and /t/), but also as part of compound names in Duwayalla, Tuwakili, Tuwastili, Tuwattaziti, etc. (for the list and references, see Laroche 1966: 193-194). 
Herodotus, 1, 153-161) ${ }^{35}$, $\Sigma \alpha \mu b \alpha \kappa \tau v \eta \varsigma$ (in Carian context; cf. $\Sigma \alpha \mu-$

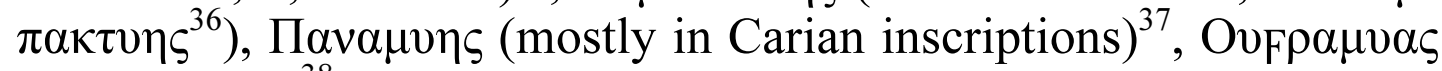
(Pamphylian) ${ }^{38}$, etc. Most of these names are compounds, sometimes also attested in inscriptions in Anatolian languages, and the

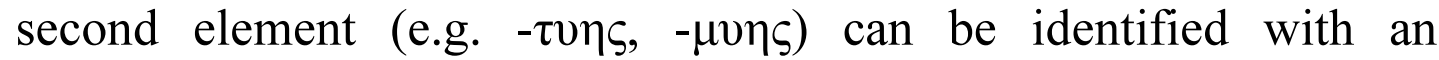

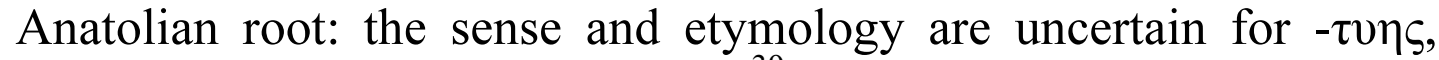
but $-\mu v \eta \varsigma$ means "descendant of...,"39.

It should be added that names of a similar kind are also attested in Greek non-epigraphic sources. Thus, we are told that the name of Thales' father was Examyes ${ }^{40}$ :

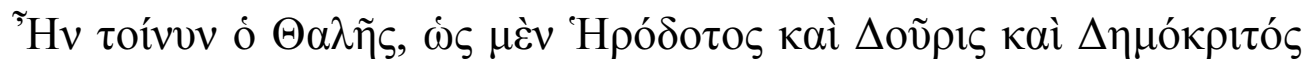

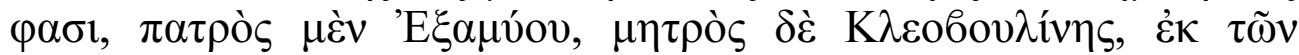

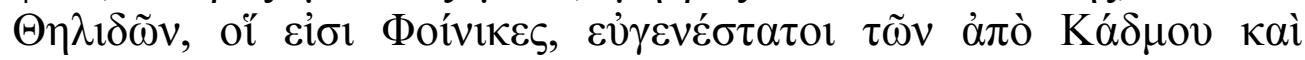
'A үүívopos (Diog. Laert. 1, 22 Dorandi).

"Thales was, according to Herodotus, Douris and Democritus, son of Examyes and Cleobouline, and belonged to the Thelidae who are Phoenicians and noblest among the descendants of Cadmos and Agenor"

And among the testimonia on Mimnermus' life a poetic appraisal of the elegist's life in Hermesianax, another Examyes is mentioned as Mimnermus' companion at feasts - piece of information that undoubtedly was taken from Mimnermus' own writings:

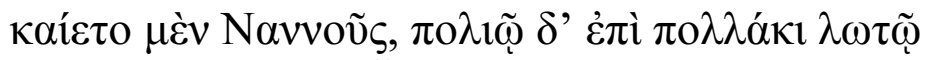

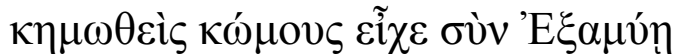

(Hermesian. fr. 3, 35-40 Lightfoot $=$ Mimn. Test. 4 Allen $)$.

${ }^{35}$ See Zgusta (1964: 403-404, § 1193), Fraser, Matthews (2010: 353, s.v.

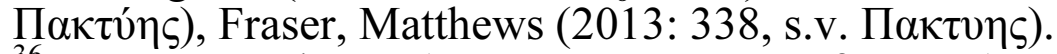

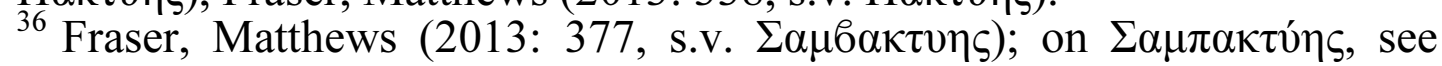
Zgusta (1964: 452, § 1364-2) who connects it with Пактúns.

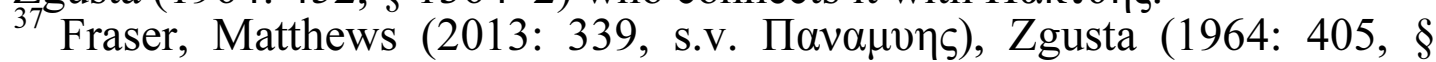
1197-6). The name is attested as Panamuwa in Hittite (see Laroche 1966: 135, no. 927; cf. Punamuwa - Laroche 1996: 158, no. 1050).

${ }^{38}$ See Fraser, Matthews (2013: 335, s.v. Ovfpauvas); the name resembles

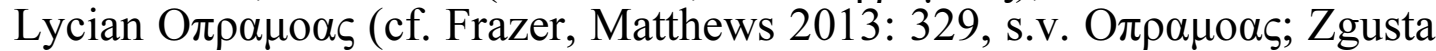

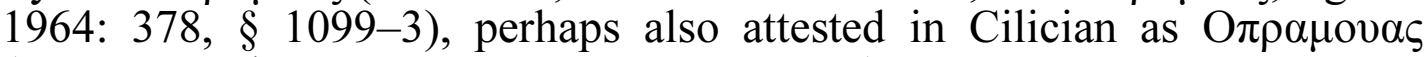

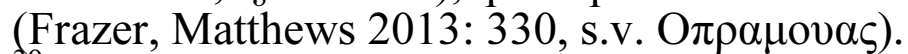

${ }^{39} \mathrm{Cf}$. Armamuwa "descendant of the Moon", Tiwatamuwa "descendant of the Sun", etc.; on these names see Laroche (1966: 290); it has been suggested that the literal meaning of -muwa seems to be "seed, seminal fluid" (cf. Gamkrelidze, Ivanov 1984: II, 818; Kazansky 2004: 89).

${ }^{40} \mathrm{Cf}$. the name Eк $\alpha \mu \eta \eta \varsigma$ attested in a Carian inscription from Labraunda;

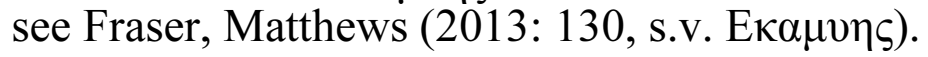


"He burned with passion for Nanno and often, muzzled onto his ancient flute, held revels with Examyes".

Names in -v́nc/-v́as thus had a certain degree of diffusion in Greek cities of Asia Minor, and the presence of another person with a name of this kind in Mimnermus' immediate entourage is certainly striking. This being said, the reconstruction of a non-Greek name for Mimnermus' father should not lead us to draw any hasty conclusions as to Mimnermus' family. Onomastic data in general demand careful treatment, and we know too little of the sociographic situation in ancient Smyrna in Mimnermus' lifetime to warrant any unequivocal conclusions. Moreover, it cannot be excluded that Ligyrtyes may already be a partly Hellenized version of a indigenous name, modified to make it resemble the Greek adjective $\lambda$ ivopós. This type of Hellenization may also be suspected in other

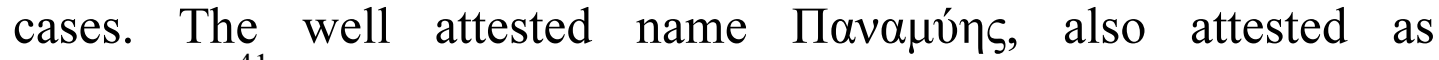
$\Pi v v \alpha \mu v \alpha \varsigma^{41}$, finds parallels in the Hittite and other Anatolian

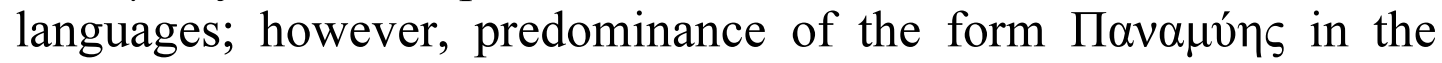
Greek inscriptions suggests that is was preferred because of the resemblance of the first root to Gk. $\pi \tilde{\alpha} \varsigma, \pi \tilde{\alpha} \sigma \alpha, \pi \tilde{\alpha} v$; and the name $\mathrm{K} 1 \delta \rho \alpha \mu v v_{\varsigma}(\mathrm{K} 1 \delta \rho \alpha \mu o v \alpha \varsigma,-\eta \varsigma)$ seems to have been modified into

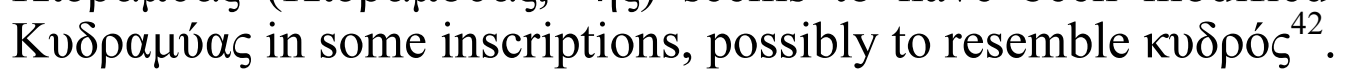

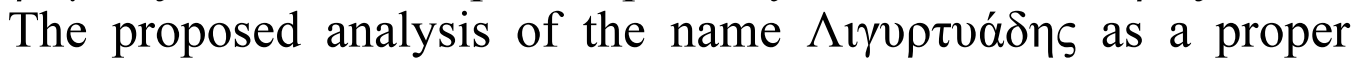
patronymic, which had been mistakenly taken for the name of the poet's father, has the advantage of introducing minimal change in the tradition, while the more interesting part of the transmitted form

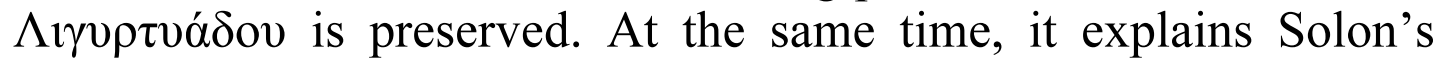
wordplay. In creating $\Lambda \downarrow v \alpha \sigma \tau \alpha \dot{\delta}\rangle\rceil \varsigma$, he was using Mimnermus'

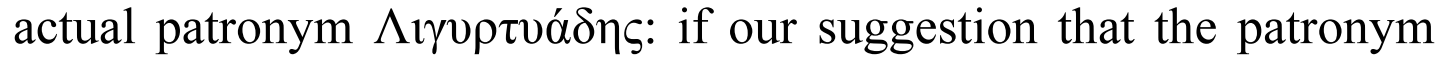
had been mentioned by Mimnermus in his sphragis is accepted, the patronym would have been known to at least a part of part of his audience that would be able to fully appreciate his pun. The first part of the father's name would have been associated with the adjective $\lambda$ iropó $\varsigma$ "clear-voiced", which permitted Solon to replace it with the $\lambda$ vovs, the shorter variant, identical from the point of view of the

${ }^{41}$ See Fraser, Matthews (2013: 371, s.v. Пvvauvas); cf. Robert (1963: 515) and Robert, Robert (1953: 179-178, no. 202). It may have helped that punna- in Luwian and Lycian also meant "all"; Laroche viewed pana- as a variant of the same form, but this idea is disputed (cf. Adiego 2007: $337-$ $338, \S 2.12)$.

${ }^{42}$ See Robert (1963: 409), with references; cf. Zgusta (1964: 260, § 767-1). 
semantics, while the patronymic suffix was transformed into a separate root and linked with the verb ö $\delta \omega$.

\section{Appendix}

A few words need to be said about the reasons that led to the confusion of patronymic with the father's name in Mimnermus'

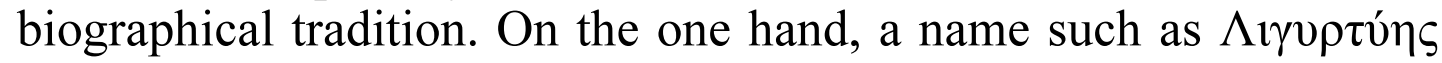
would have sounded strange to a Greek reader, and if it was only

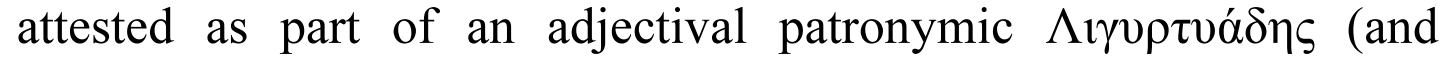
especially if, as we suggested, it was used in the genitive), grammarians would have been tempted to treat it as a proper name

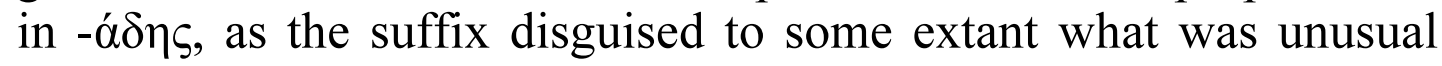
about the name, giving it a form that was closer to Greek. On the other hand, Solon's name for Mimnermus, $\Lambda$ $\gamma v \alpha \sigma \sigma \alpha \dot{\delta} \delta\rceil$, which was probably incorporated into the elegist's biographical tradition no later than early Hellenistic times ${ }^{43}$, would have precluded the

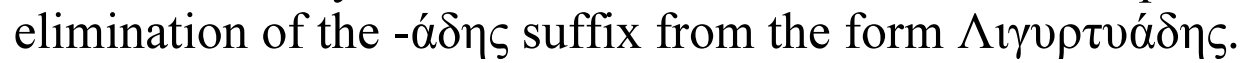

But there was also a much more specific reason why the compiler of Mimnermus' biography would have been comfortable

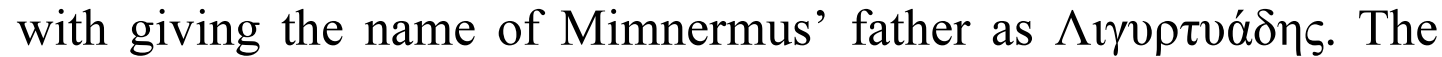
ancient scholia preserve a strand of exegesis which explained that in

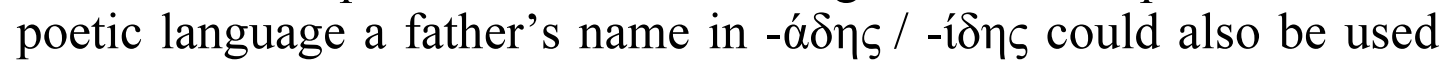
as his son's patronym. This explanation appears only sporadically and was in all likelihood invented as ad hoc explanation of some of

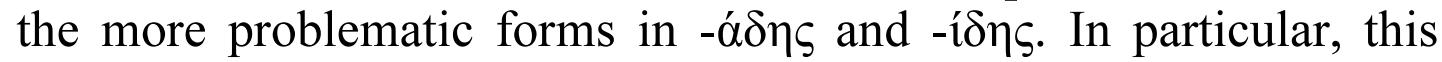
explanation was used, and probably invented, by Aristarchus:

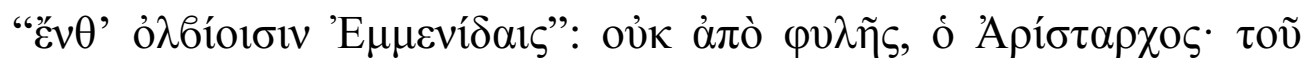

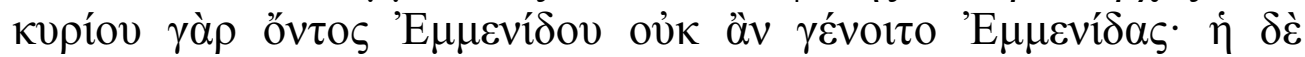

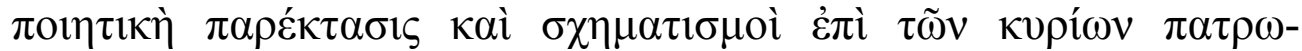

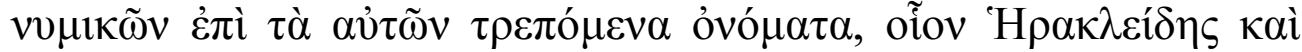

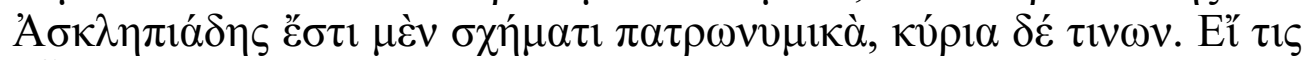

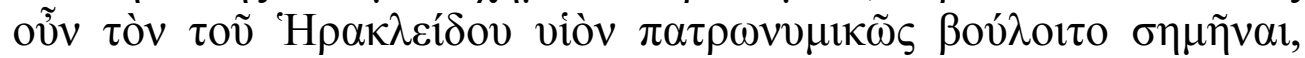

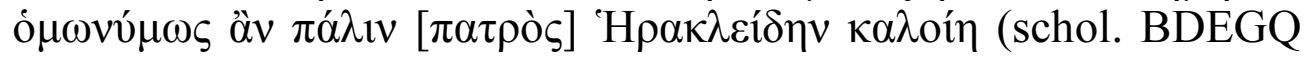
in Pind. Pyth. 6, 5a Drachmann).

\footnotetext{
${ }^{43}$ Diogenes Laertius writing in the III century AD who preserves Solon's dialogue with Mimnermus is the obvious terminus ante quem for the story's entry in the biographical tradition of the two poets. However, the revival of interest in Mimnermus at the beginning of the Hellenistic age renders an earlier date much more probable.
} 
" 'There for the fortunate Emmenidai': [called thus] not from their clan ${ }^{44}$, as Aristarchus [argued]: for the original name being Emmenides, the derivative would not be Emmenides ${ }^{45}$. This is a poetic extension [of usage of the name] to their own names, producing a trope - as well as a formation based on actual patronyms, just as Heracleides and Asclepiades are, by their form, patronymics, but proper names of some people. And thus if someone wanted to designate Heracleides' son by a patronym, he would call him in his turn Heracleides, homonymously with his father"

Aristarchus considered Pindar's expression ò $\lambda$ bíoıøıv 'E $\mu \mu \varepsilon-$

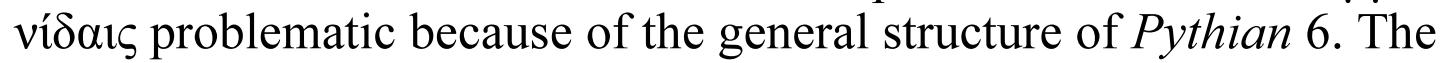
ode celebrates a chariot victory of Xenocrates of Acragas, brother of Theron, the tyrant of Acragas, but besides the actual laudandus, Xenocrates, his son, Thrasybulus, receives an unexpected amount of

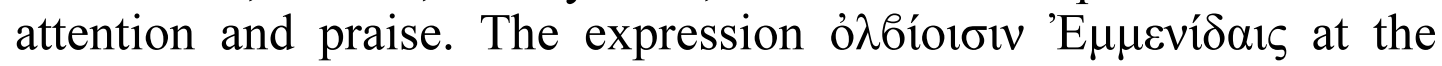
very beginning of the ode (Pyth. 6, 5) has to be understood as referring to the three family members. The origins of the family name 'E $\mu \mu \varepsilon v i \delta \alpha 1$ were explained in different ways in Antiquity ${ }^{46}$, but Aristarchus obviously preferred the genealogy according to Theron's and Xenocrates' grandfather was called Emmenides. The fact that the descendants of an 'E $\mu \mu \varepsilon v i ́ \delta \eta \varsigma$ Emmenides were themselves called 'E $\mu \mu \varepsilon v i \delta \alpha$ went contrary to the accepted usage and had to be explained: thus, according to Aristarchus, the transfer of a name that was patronymic in form from the father to the son was a kind of poetic trope. The wording of the scholium shows that the homonymy of this kind could in no way be considered normal

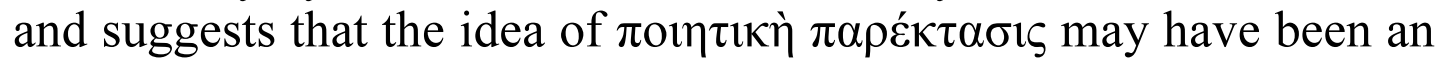
exegetical subterfuge invented for this passage in particular (or a limited number of uncomfortable cases). There is one other case where it figures prominently - in Theocritus' short biography transmitted in the scholia:

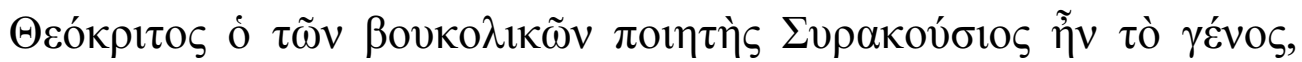

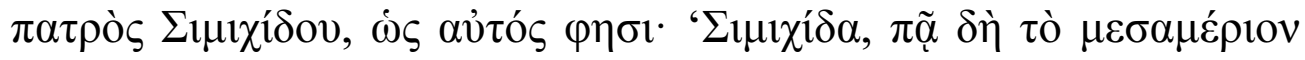

\footnotetext{
${ }^{44}$ Given the scholiast's brevity, it is difficult to be sure of the exact meaning of $\varphi v \lambda \eta$ in this context: Miller translates it as "tribe (?)", considering that "it should mean [Aristarchus] denied it was the name of any kind of descent or kinship group" (Miller 1970: 54). The remark ov่k ámò $\varphi v \lambda \tilde{\eta} \varsigma$ was probably polemic in nature, rejecting the explanation that the Emmenids were a $\varphi \rho \alpha ́ \tau \rho 1 \alpha$ (schol. in Pind. O1. 3, 67b, 68b Drachmann). ${ }^{45}$ 'E $\mu \mu \varepsilon v i \delta \alpha \varsigma$ in the text of the scholium is manifestly a Doric form which we have rendered as the more regular form Emmenides in our translation. ${ }^{46}$ For a list and analysis of the ancient sources on the origins of the name

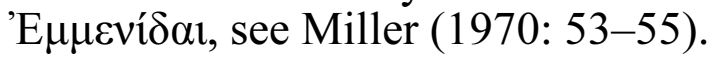




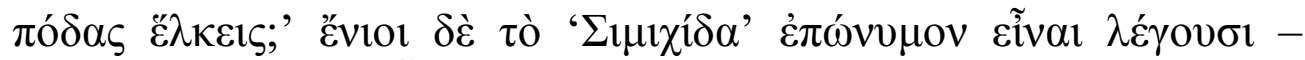

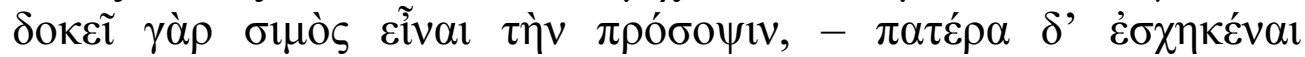

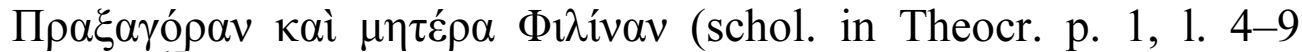
Wendel $^{47}$ ).

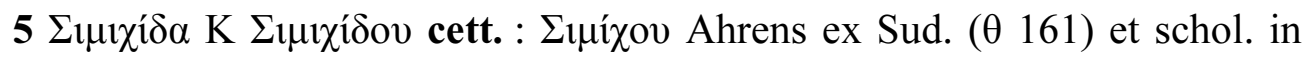

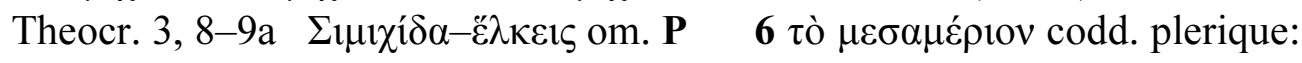

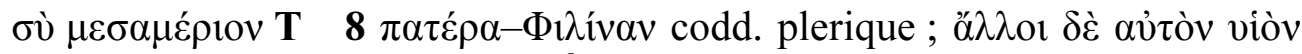

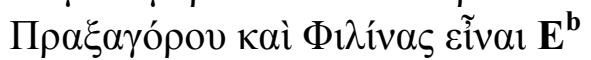

"Theocritus, writer of bucolic poetry was Syracusian by his descent, son of Simichidas, as he says himself: 'Simichidas, where are you steering your steps this noon?' (Theocr. 7, 21). Others say that 'Simichidas' was his surname - for he seemed snub-nosed in his appearance, - whereas his father was Praxagoras and his mother Philinna".

We know from other ancient sources on Theocritus' life that the poet's parents were Praxagoras and Philinna ${ }^{48}$, but the compiler of this biography preferred the alternative version that stemmed from the equation of the narrator of Idyll 7, Simichidas, with Theocritus (as is evident from his quotation of Lycidas' address to him, Id. 7, 21). However, he failed to notice, or rather deliberately ignored, the contradiction between his own words $\pi \alpha \tau \rho \mathrm{òs} \Sigma \mu 1 \chi i$ íov and the use of $\Sigma \mu 1 \chi i \delta \alpha$ as a patronymic in the quotation he uses to argue his version of Theocritus' parentage. Ahrens, suspecting an error in the manuscript reading $\Sigma \mu \imath \chi$ ídov under the influence of the apostrophe $\Sigma \mu \imath \chi i \delta \alpha$, corrected it to $\Sigma \mu$ í $\chi 0 v$, based on Theocritus' biography in the Suda $(\theta 166=$ II, p. 697, 1. 18-19 Adler) and one of the scholia where the assumed father's name appears as $\Sigma$ í $\chi_{\chi 0} \varsigma^{49}$. However, $\Sigma \mu \imath \chi i \delta o v$ is visibly more than a lapsus calami (and, incidentally, should not perhaps be eliminated from the main text, if only for the interest that it has for the history of ancient literary criticism) - later on a scholiast goes out of his way (in his note on $I d .7,21$ ) to

${ }^{47}$ The abbreviation of manuscripts follows that used by C. Wendel in his edition: $\mathbf{K}$ - codex Ambrosianus 886; $\mathbf{P}$ - codex Laurentianus XXXII 37; T - codex Vaticanus 38; E - codex Vaticanus 42. The text and the apparatus criticus quoted above differ slightly from Wendel's edition: in particular, we reintroduced the ms. reading $\Sigma \uparrow \mu \imath \chi i \delta o v$ in the main text and relegated Ahrens' correction $\Sigma$ ¿uí $\chi 0 v$ to the apparatus.

${ }^{48}$ See Gow (1965: I, XVI and II, 128). The names of Praxagoras and

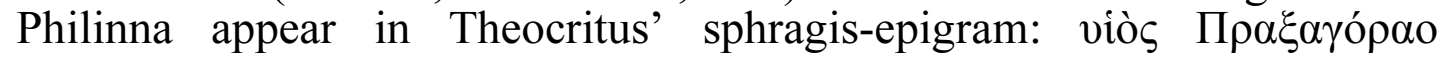

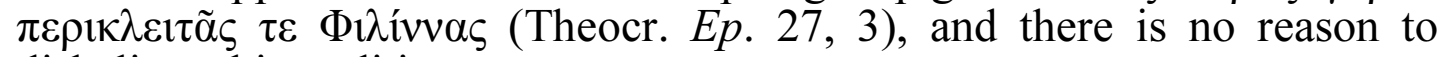
disbelieve this tradition.

${ }^{49}$ Schol. in Theocr. Ahrens (1859: 1); this reading is accepted by Wendel (1914: 1) and Gow (1965: I, XV). 
explain that there is nothing awkward in having the same name appear as the father's name and the son's patronymic:

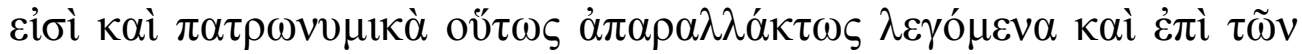

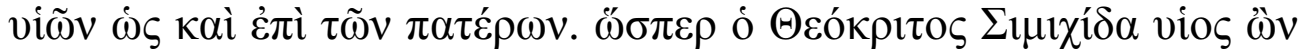

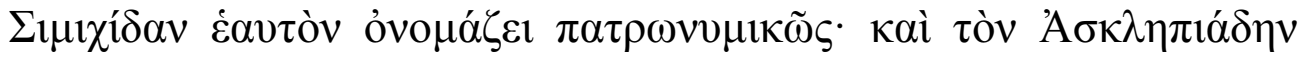

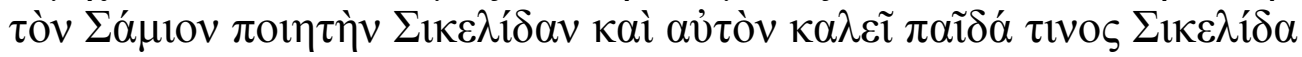

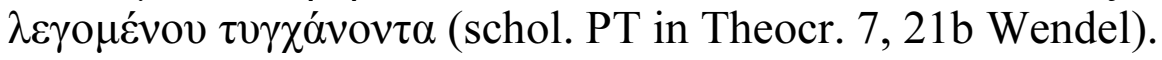

"There exist patronyms that are used thus without modification of form both of the sons and of the fathers. Even as Theocritus, being the son of Simichidas, calls himself Simichidas in a patronymic way; and calls Asclepiades, poet from Samos, 'Sicelides', as $h$ happened to be the son of a certain Sicelides".

This scholium uses one and the same approach to explain $\Sigma \mu 1 \chi i \delta \alpha \varsigma$ (which the scholiast wanted to stand for Theocritus) and $\Sigma 1 \kappa \varepsilon \lambda i$ ías (for Asclepiades of Samos; cf. schol. in Theocr. 7, 40b). In neither case is his explanation a lucky one: the suggestion that Theocritus' father's name could be reconstructed as $\Sigma \mu 1 \chi i \delta \alpha \varsigma$ was obviously questioned already in Antiquity; as for $\Sigma 1 \kappa \varepsilon \lambda i \delta \alpha \varsigma$ - the form with the patronymic suffix was a fairly common designation of Asclepiades, but not as a patronym, but as a nickname ${ }^{50}$.

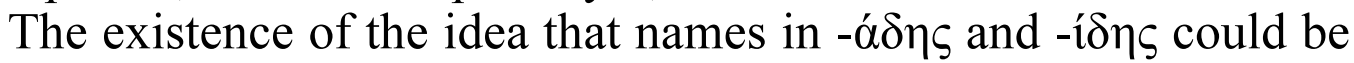
used both as father's names and their son's patronymic seems to have allowed the compiler of the Suda entry on Mimnermus (or his source) to reconstruct the name of Mimnermus' father as

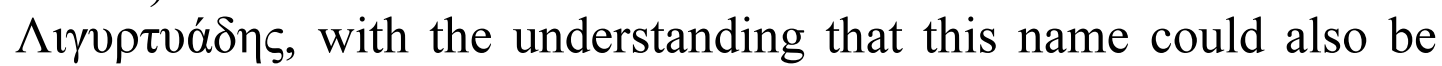

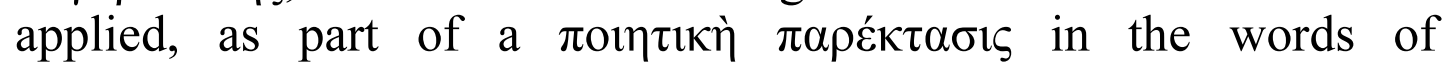
Aristarchus, to Mimnermus himself. In that case there would have been no contradiction, in the eyes of the compiler of the Suda entry (or of an earlier biographer on whom the compiler relied), between

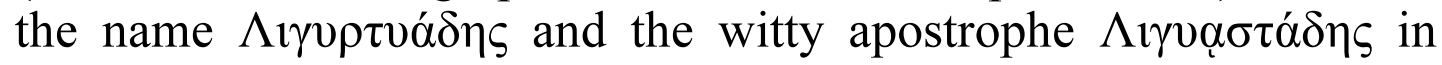
Solon.

\section{References}

Adler, A. (ed.) 1928-1938: Suidae Lexicon, vol. I-V. Stuttgart.

Ahrens, H. L. (ed.) 1859: Bucolicorum Graecorum Theocriti Bionis Moschi reliquiae accedentibus incertorum idylliis, Vol. II: Scholia. Lipsiae.

Allen, A. (ed., comm.) 1993: The Fragments of Mimnermus, Text and Commentary. Stuttgart.

${ }^{50}$ See Sens (2011: XXIX-XXXI) for the references and a detailed discussion of the probable biographical reasons behind Asclepiades' nickname Sicelides. 
Bach, N. (ed.) 1826: Mimnermi Colophonii carminum quae supersunt. Leipzig.

Bagordo, A. 2011: Lyrik. In: B. Zimmermann (Hrsg.) Handbuch der griechischen Literatur der Antike, Bd. I: Die Literatur der archaischen und klassischen Zeit. München, 124-249.

Barron, J. P. Easterling, P. E. 1985: Early Greek Elegy: Callinus, Mimnermus, Tyrtaeus. In: B. M. W. Knox, P. E. Easterling (eds.) The Cambridge History of Classical Literature, vol. I: Greek Literature. Cambridge, 128-136.

Bergk, Th. (ed.) 1843. Poetae lyrici Graeci. Lipsiae.

Campbell, D. A. 1967: Greek Lyric Poetry, A Selection of Early Greek Lyric, Elegiac and Iambic Poetry. New York.

Carden, R. (ed., comm.) 1974: The Papyrus Fragments of Sophocles, an edition with prolegomena and commentary, with a contribution by W. S. Barrett. Berlin, New York.

Diehl, E. (ed.) 1954. Anthologia lyrica Graeca. Fasc. I: Poetae elegiaci. Leipzig.

Diels, H. 1902: Onomatologisches. Hermes 37, 480-483.

Dorandi, T. (ed.) 2013: Diogenes Laertius, Lives of Eminent Philosophers, edited with introduction. Cambridge; New York.

Dovatour, A. I. 1982: Solon i Mimnerm, poeticheskaya polemika po povodu raznogo vospriyatiya zhizni [Solon and Mimnermus: Poetic Polemic on Different Views on Life]. Philologia classica 2, 55-62. Доватур, А. И. 1982: Солон и Мимнерм, поэтическая полемика по поводу разного восприятия жизни. Philologia classica 2, 5562.

Drachmann, A. B. (ed.) 1910: Scholia vetera in Pindari carmina, vol. I-III. Leipzig.

Edmonds, J. M. (ed., trans1.) 1931: Elegy and Iambus, being the remains of all the Greek elegiac and iambic poets from Callinus to Crates. Vol. I. Cambridge Mass., London.

Ford, A. 2004: Origins of Criticism: Literary Culture and Poetic Theory in Classical Greece. Princeton NJ; Oxford.

Fraser, P. M. Matthews, E. (eds.) 2010: A Lexicon of Greek Personal Names. Vol. V.A: Coastal Asia Minor, Pontos to Ionia / ed. T. Corsten. Oxford.

Fraser, P. M. Matthews, E. (eds.) 2013: A Lexicon of Greek Personal Names. Vol. V.B: Coastal Asia Minor, Caria to Cilicia / ed. J.-S. Balzat, R. W. V. Catling, É. Chiricat, F. Marchand, associate editor T. Corsten. Oxford.

Gamkrelidze, T.V. Ivanov, V.V. 1984: Indoevropeyskiy yazyik $i$ indoevropeytsy [The Indo-European Language and IndoEuropeans]. Tbilisi.

Гамкрелидзе, Т. В. Иванов, В. В. 1984: Индоевропейский язык и индоевропейиы. Тбилиси.

Gentili, B., Prato, C. (eds.) 1979: Poetarum elegiacorum testimonia et fragmenta. Pars I. Leipzig.

Gerber, D. E. 1970: Euterpe. An Anthology of Early Greek Lyric, Elegiac, and Iambic Poetry, edited with introductory remarks and commentary. Amsterdam. 
Gow, A. S. F. (ed., comm.) 1965: Theocritus, edited with a translation and commentary. Vol. I-II. Cambridge.

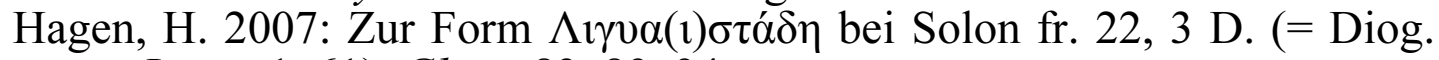
Laert. 1, 61). Glotta 83, 89-94.

Hubbard, Th. 2007: Theognis' Sphrêgis: Aristocratic Speech and the Paradoxes of Writing. In: C. Cooper (ed.) Politics of Orality. Leiden, Boston. 193-215.

Hudson-Williams, Th. (ed., comm.) 1926: Early Greek Elegy: The Elegiac Fragments of Callinus, Archilochus, Mimnermus, Tyrtaeus, Solon, Xenophanes \& others. Cardiff.

Kazansky, N. N. 2004: [Hippocrates' corpus and its Significance for Modern Humanities]. Trudy Otdeleniya istoriko-filologichskih nauk RAN 2, 88-91.

Казанский, Н. Н. 2004: Гиппократов корпус и его значение для современного гуманитарного знания. Tруды Отделения историко-филологических наук РАН, вып. 2.2004 г., 88-91.

Kranz, W. 1961: Sphragis. Ichform und Namensiegel als Eingangs- und Schlußmotif antiker Dichtung. Rheinisches Museum 104.1, 3-46; Rheinisches Museum 104.2, 97-124.

Laroche, E. 1966: Les noms des hittites (Études linguistiques IV). Paris.

Maas, P. 1932: s.v. Mimnermos. In: Paulys Realencyclopädie der klassischen Altertumswissenschaft, Bd. 15.2. Stuttgart, 1725-1727.

Marcovich, M. (ed.) 1999. Diogenes Laertius, Vitae philosophum. Vol. I: libri I-X. Stuttgart, Leipzig.

Masaracchia, A. 1958: Solone. Firenze.

Meyer, G. 1923: Die stilistische Verwendung der Nominalkomposition im Griechischen (Philologus Supplementband 16.3). Leipzig.

Miller, M. 1970: The Sicilian Colony Dates. Studies in Chronography, I. Albany.

Müller, C. W. 1988: Die antike Buchausgabe des Mimnermos. Rheinisches Museum 131, 197-211.

Nisbet, R. G. M. Hubbard, M. 1978: A Commentary on Horace. Odes, book II. Oxford.

Noussia-Fantuzzi, M. (ed., comm.) 2010: Solon the Athenian, the Poetic Fragments. Leiden, Boston.

Perrotta, G., Gentili, B. (ed., comm.) 1965: Polinnia, poesia greca arcaica. Mesina, Firenze.

Robert, J. Robert, L. 1953: Bulletin épigraphique. Revue des études grecques 66 (fascicule 309-310), 113-212.

Robert, L. 1963: Noms indigènes dans l'Asie Mineure gréco-romaine, Part I. Paris.

Sanz Morales, M. 2011: La cronología de Mimnermo. Eikasmos 11, 29-52.

Schmid, W. Stählin, O. 1929: Geschichte der griechischen Literatur. Bd. I.1. München.

Sens, A. (ed., comm.) 2011: Asclepiades of Samos, Epigrams and Fragments, edited with translation and commentary. Oxford, New York.

Steffen, V. 1955: Quaestiones lyricae. Poznań. 
Szádeczky-Kardoss, S. 1968: s.v. Mimnermos. In: Paulys Realencyclopädie der klassischen Altertumswissenschaft, Suppl. Bd. 11. Stuttgart, 935-951.

Tuomi, R. 1986: Kaì võv, Solons Gedicht an Mimnermos im Lichte der Tradition. Turku.

Wendel, C. (ed.) 1914: Scholia in Theocritum vetera. Stuttgart.

West, M. L. (ed.) 1980: Delectus ex iambis et elegis Graecis. Oxford.

West, M. L. (ed.) 1992: Iambi et elegi Graeci ante Alexandrum cantati. Vol. II. Oxford ( $2^{\text {nd }}$ ed. $)$.

West, M. L. 1974: Studies in Greek Elegy and Iambus. Berlin, New York.

Wilamowitz-Moellendorff, U. von. 1913: Sappho und Simonides. Untersuchungen über griechische Lyriker. Berlin.

Woodbury, L. 1952: The Seal of Theognis. In: M. E. White (ed.) Studies in Honour of Gilbert Norwood (Phoenix Supplementary Volume 1). Toronto, 20-41.

Zgusta, L. 1964: Kleinasiatische Personennamen. Prag.

Summary. The name of Mimnermus' father is transmitted by the Suda in a biographical entry $(\mu$ 1077) that introduces the poet as Mí $\mu v \varepsilon \rho \mu$ s $\Lambda$ « Although a priori there is little reason to doubt the transmitted form, it is difficult to reconcile it with Solon's address to Mimnermus as

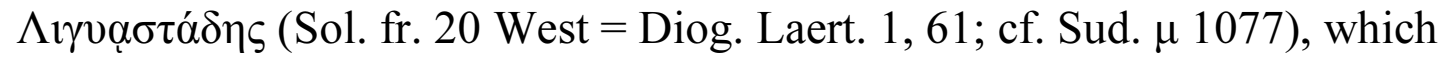
manifestly is a compliment to Mimnermus but seems to make the name of Mimnermus' father rather than the poet's own name the object of the pun. The article examines the advantages and the disadvantages of existing approaches to this problem and proposes a different solution, arguing that

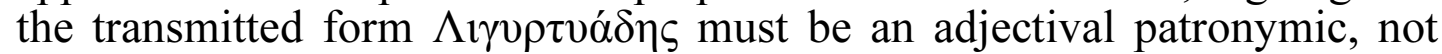
the actual name of Mimnermus' father.

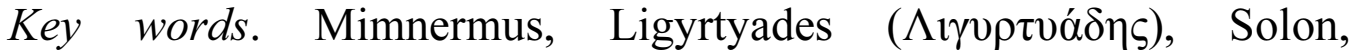
patronymic, Suda, Diogenes Laertius, ancient scholarship, onomastics of Asia Minor. 